\title{
Purification and characterisation of intracellular toxin $A$ of Clostridium difficile
}

\author{
X. Q. MENG, S. KAMIYA*, K. YAMAKAWA, H. OGURA and S. NAKAMURA $\dagger$ \\ Department of Bacteriology, School of Medicine, Kanazawa University, Kanazawa 920, Japan
}

\begin{abstract}
Summary. After sonic disintegration of Clostridium difficile cells, intracellular toxin A was purified to homogeneity by thyroglobulin affinity chromatography (TGAC) followed by anion-exchange (Mono Q) by fast protein liquid chromatography (FPLC). High haemagglutinating (HA) activity was detected in TGAC-unbound fractions $\left(2^{9} / 50 \mu l\right)$, but not in TGAC thermal eluates $\left(2^{0} / 50 \mu 1\right)$. The low HA titre of the thermal eluates was markedly increased to $2^{5} / 50 \mu \mathrm{l}$ after dialysis against $0.02 \mathrm{M}$ Tris- $\mathrm{HCl}(\mathrm{pH} 7.5)$. A disparity in the position of the peaks containing cytotoxic and HA activity was observed in the first Mono QFPLC step. Intracellular toxin A without HA activity was obtained by a second Mono QFPLC step. The $M_{r}$ of the intracellular toxin $A$ was estimated by polyacrylamide gel electrophoresis (PAGE) to be $580 \mathrm{kDa}$ under non-denaturing conditions. The minimum doses of the toxin causing cytotoxicity, mouse lethality and enterotoxicity were $0.83 \mathrm{ng}$, $8.7 \mathrm{ng}$ and $5 \mu \mathrm{g}$, respectively.
\end{abstract}

\section{Introduction}

Among the various virulence factors proposed for Clostridium difficile, e.g., toxins $\mathrm{A}$ and $\mathrm{B},{ }^{1-4}$ factors related to mucosal association, ${ }^{5}$ tissue degradative enzymes, ${ }^{6}$ fimbriae $^{7}$ and capsule, ${ }^{8}$ toxin $\mathrm{A}$ has been considered to be the most important because of its enterotoxicity. The $M_{r}$ values of toxin $A$ in non-denaturing and denaturing conditions were reported to be $400-600 \mathrm{kDa}$ and $200-250 \mathrm{kDa}$, respectively. ${ }^{1-4,9,10}$ This toxin has various biological activities such as enterotoxicity, vascular permeabilityincreasing activity, mouse lethality, cytotoxicity and haemagglutinating (HA) activity. ${ }^{1-4,9}$ These findings were mainly obtained from extracellular toxin A released into culture medium, and few studies on intracellular toxin A have been performed. In the present study, intracellular toxin A was purified, and characterised biochemically and biologically.

\section{Materials and methods}

\section{Bacterial strains and preparation of cell extract}

A 4-ml volume of $C$. difficile strain VPI 10463 cultured anaerobically at $37^{\circ} \mathrm{C}$ for $18 \mathrm{~h}$ in liver broth was inoculated into $4 \mathrm{~L}$ of Brain Heart Infusion Broth

Received 15 Jan. 1992; revised version accepted 16 June 1992.

* Present address: Department of Microbiology, School of Medicine, Tokai University, Bohseidai, Isehara, Kanagawa 259-11, Japan.

$\dagger$ Correspondence should be sent to Professor S. Nakamura.
(BHI; Becton Dickinson Microbiology System, Cockeysville, MD, USA) supplemented with

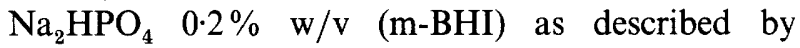
Nakamura et al., ${ }^{11}$ and incubated anaerobically at $37^{\circ} \mathrm{C}$ for 2 days. The culture was centrifuged and the sediment was washed twice with $0.05 \mathrm{M}$ Tris- $\mathrm{HCl}$, $0 \cdot 15 \mathrm{M} \mathrm{NaCl}, \mathrm{pH} 7 \cdot 0$ (TBS). The washed sediment was suspended in $60 \mathrm{ml}$ of TBS and sonicated for $7.5 \mathrm{~min}$ with a Tomy ultrasonic vibrator (model UR-200P, $20 \mathrm{kc}$ ) (Tomy Seiko, Tokyo, Japan). The bacterial debris was removed by centrifugation at $12000 \mathrm{~g}$ for $20 \mathrm{~min}$, and the supernate was filtered through a $0 \cdot 22-$ $\mu \mathrm{m}$ membrane filter Millex-GV (Nihon Millipore, Yonezawa, Japan).

\section{Bovine thyroglobulin affinity chromatography (TGAC)}

The method was based on that of Krivan and Wilkins. ${ }^{9}$ Briefly, $60 \mathrm{ml}$ of cell extract was applied to the column at $4^{\circ} \mathrm{C}$. After washing the column with $30 \mathrm{ml}$ of TBS at $4^{\circ} \mathrm{C}$, thermal elution was performed by washing with $40 \mathrm{ml}$ of pre-warmed TBS at $37^{\circ} \mathrm{C}$. Fractions $(5 \mathrm{ml})$ were collected and monitored for absorbance at $280 \mathrm{~nm}\left(\mathrm{~A}_{280}\right)$, cytotoxicity and HA activity as described below.

\section{Anion-exchange chromatography}

An anion-exchange gel, Mono Q (Pharmacia LKB Biotechnology, Uppsala, Sweden), incorporated into a fast protein liquid chromatography (FPLC) apparatus (Pharmacia LKB Biotechnology) was used as de- 
scribed previously. ${ }^{10}$ The sample was filtered $(0 \cdot 22-\mu \mathrm{m}$ membrane) before being applied to the column, and elution by a $0-0.4 \mathrm{M} \mathrm{NaCl}$ linear gradient in $20 \mathrm{~mm}$ Tris- $\mathrm{HCl}(\mathrm{pH} \mathrm{7.5)}$ was performed at a flow rate of $0.5 \mathrm{ml} / \mathrm{min}$. Each fraction $(0.5 \mathrm{ml})$ was examined for $\mathrm{A}_{\mathrm{Ex} 0 .}$. cytotoxicity and HA activity.

\section{$P A G E$}

The method was based on that of Kamiya et al. ${ }^{10}$ The gels were silver stained (BioRad Laboratories, Richmond. CA, USA), according to the manufacturer's instructions (BioRad Bulletin 1089). An electrophoresis calibration kit (Pharmacia LKB Biotechnology) was used for estimation of $\mathbf{M}_{r}$. Native PAGE in non-denaturing conditions was performed in a $415 \%$ gel. Samples were electrophoresed at $125 \mathrm{~V}$ for $18 \mathrm{~h}$ after initial electrophoresis at $8 \mathrm{~mA}$ for $30 \mathrm{~min}$.

\section{Crtotoxicity assay}

Cytotoxicity was determined with baby hamster kidney (BHK-21/WI-2) cells as described by Nakamura $e t$ al. ${ }^{11}$ The cytotoxic titre (CU) $/ 50 \mu \mathrm{l}$ was expressed as the dilution that induced a $100 \%$ cytopathic effect after incubation at $37^{\circ} \mathrm{C}$ for $48 \mathrm{~h}$. $\mathrm{CU}_{50}$ was calculated according to the results of six cytotoxic titrations of one specimen.

\section{HA assay}

This assay was based on the method described by Krivan et al. ${ }^{12}$ with a slight modification in that a rabbit erythrocyte $1.5 \%$ suspension was used instead of $2.5 \%$. Two-fold serial dilutions of toxin preparations $(50 \mu \mathrm{l})$ were performed with $0.05 \mathrm{M}$ Tris- $\mathrm{HCl}$, $0.1 \mathrm{M} \mathrm{NaCl}$. pH 7.2. in the wells of U-bottom microtitration plates (Greiner, Nurtingen, Germany); $50 \mu \mathrm{l}$ of blood-cell suspension was added to each well and allowed to react for $3 \mathrm{~h}$ at $4^{\circ} \mathrm{C}$. The $\mathrm{HA}$ titre was expressed as the highest dilution of the specimen that caused macroscopic HA.

\section{Mouse lethality.}

Serial two-fold diluted toxin preparations in saline $(0.5 \mathrm{ml})$ were injected intraperitoneally into a mouse. The activity was expressed as $50 \%$ lethal dose $\left(\mathrm{LD}_{\overline{5} 0}\right)$.

\section{Ruhbit ileal loop response test}

Ligated intestinal loops (seven loops/rabbit with each loop $7-10 \mathrm{~cm}$ in length) were prepared in Japanese white rabbits $(1.7-2.0 \mathrm{~kg})$ according to the method of De and Chatterje. ${ }^{13}$ One-ml samples were injected into ligated ileal loops. The fluid which accumulated in each loop was examined $16 \mathrm{~h}$ after the injection. The intensity of the response was expressed as the ratio of fluid volume $(\mathrm{ml})$ accumulated to the length $(\mathrm{cm})$ of the loop.

\section{Protein assay}

Protein was quantitated by the dye-binding method of Bradford ${ }^{14}$ with the BioRad protein assay kit (BioRad Laboratories). Bovine serum albumin (Wako Pure Chemical, Osaka, Japan) was used as a standard.

\section{Results}

\section{Purification of intracellular toxin A}

The extract of sonic disintegrated cells was applied to TGAC at $4^{\circ} \mathrm{C}$ followed by washing with $30 \mathrm{ml}$ of TBS at $4^{\circ} \mathrm{C}$, and thermal elution at $37^{\circ} \mathrm{C}$ of toxin $\mathrm{A}$ was performed (fig. 1.). The TGAC-unbound fractions (fr 2-13) had $2^{15} \mathrm{CU} / 50 \mu$ of cytotoxicity and $2^{9} / 50 \mu \mathrm{l}$ of HA activity, showing that almost no HA activity substance of the cell extract bound to thyroglobulin. The first fraction (fr 19) of the thermal eluates was shown to have high cytotoxicity $\left(2^{11} \mathrm{CU} / 50 \mu \mathrm{l}\right)$ but low HA activity $\left(2^{0} / 50 \mu \mathrm{l}\right)$. The thermal eluates (fr 19-22) were dialysed at $4^{\circ} \mathrm{C}$ overnight against $0.02 \mathrm{M}$ Tris- $\mathrm{HCl} \quad(\mathrm{pH} 7.5)$ before Mono Q-FPLC. Interestingly, the $\mathrm{HA}$ titre of the thermal eluates was markedly increased to $2^{5} / 50 \mu \mathrm{l}$ after dialysis.

The thermal eluates $(21 \mathrm{ml})$ were applied to Mono Q-FPLC and a $0-0.4 \mathrm{M} \mathrm{NaCl}$ gradient elution was performed (fig. 2). The fr 30-32 eluted at 0.24-0.26 M $\mathrm{NaCl}$ showed high cytotoxicity $\left(2^{10}{ }^{12} \mathrm{CU} / 50 \mu \mathrm{l}\right)$ coincident with the peak of $A_{280}(0 \cdot 40)$. In contrast, the highest HA titre $\left(2^{6} / 50 \mu \mathrm{l}\right)$ was detected in fr 35 eluted at $0.28 \mathrm{M} \mathrm{NaCl}$ in spite of a very low $A_{280}$ value, indicating a disparity in the position of the peaks displaying cytotoxic and HA activity. Cytotoxicity $\left(2^{6} \mathrm{CU} / 50 \mu \mathrm{l}\right)$ and relatively high HA activity $\left(2^{3} / 50 \mu \mathrm{l}\right)$ were also detected in fr 37-39 eluted at $0.30-0.31 \mathrm{M} \mathrm{NaCl}$, forming a shoulder in the profile of each activity. These fractions were followed by a coincidental decrease in cytotoxicity and HA activity. The cytotoxic fractions without HA activity (fr 30-32, $1.5 \mathrm{ml}$ ) were dialysed and applied again to Mono QFPLC (fig. 3). A peak showing cytotoxicity in fr 30-34 eluted at $0 \cdot 24-0 \cdot 27 \mathrm{M} \mathrm{NaCl}$, had no HA activity at all. Highly purified cytotoxic fractions (fr 30-32) without $\mathrm{HA}$ activity were designated intracellular toxin $\mathrm{A}$ and analysed further.

\section{Yield of purified intracellular toxin $A$}

The yield of purified intracellular toxin $\mathrm{A}$ is shown in the table. The protein concentration of the purified toxin A preparation $(1.5 \mathrm{ml})$ was $30 \mu \mathrm{g} / \mathrm{ml}$, showing specific activity of $1.21 \times 10^{6} \mathrm{CU} / \mathrm{mg}$ of protein. From TGAC thermal eluates, $28.7 \%$ of the cytotoxicity was 


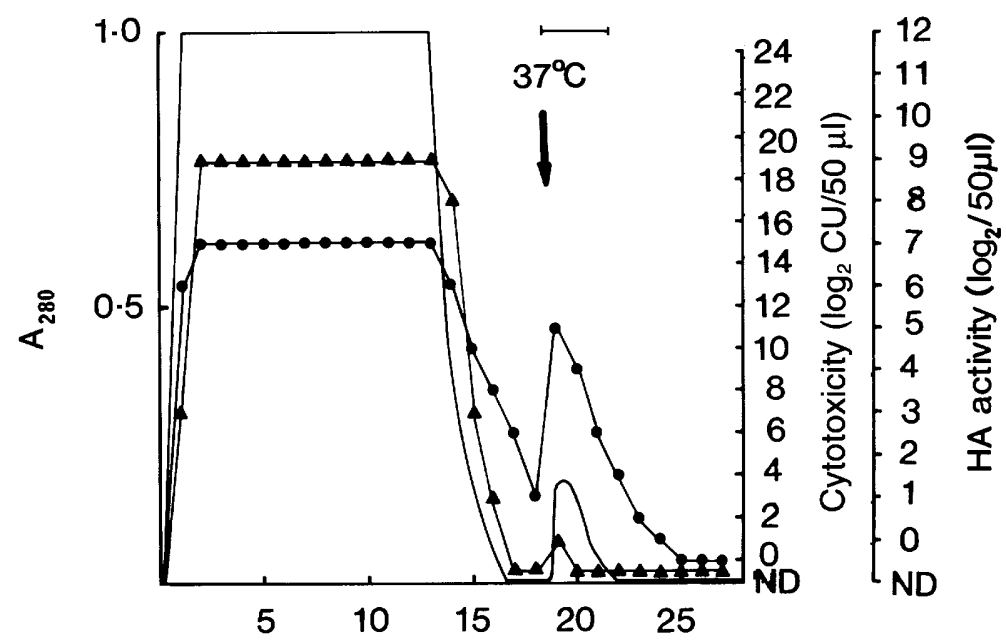

Fraction number

Fig. 1. Bovine thyroglobulin affinity chromatography (TGAC) of a cell extract of $C$. difficile after sonic disintegration. Cell extract (60 ml) was applied to the affinity column, and 5 - $\mathrm{ml}$ fractions were collected at $4^{\circ} \mathrm{C}$. From fraction $19(\downarrow)$, thermal elution was performed at $37^{\circ} \mathrm{C}$. $\longrightarrow$, cytotoxicity; $\boldsymbol{\Delta}-\mathrm{AA}$ activity; $-\mathrm{A}_{280}$.

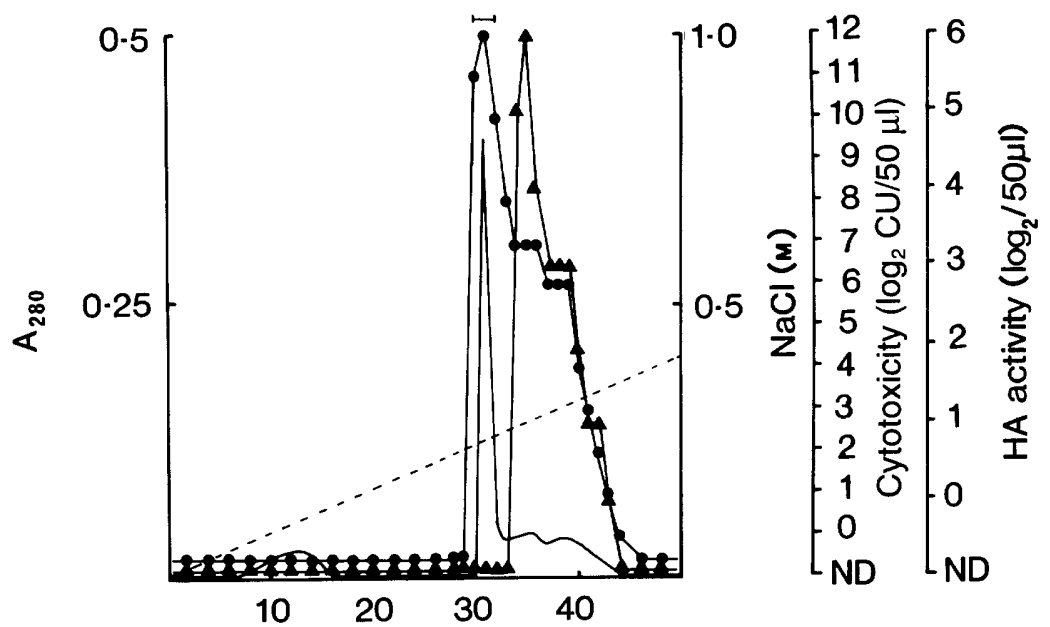

Fraction number

Fig. 2. Mono $\mathrm{Q}$ anion-exchange chromatography profile of the thermal eluates from TGAC; $21 \mathrm{ml}$ of the eluates was applied to the Mono $\mathrm{Q}$ column. Each $0 \cdot 5-\mathrm{ml}$ fraction collected was examined for $\mathrm{A}_{280}(-)$, cytotoxicity $(-\longrightarrow)$ and $\mathrm{HA}$ activity $(\boldsymbol{\Delta}-\mathbf{\Delta}) ;-\cdots$, molar concentration of $\mathrm{NaCl}$.

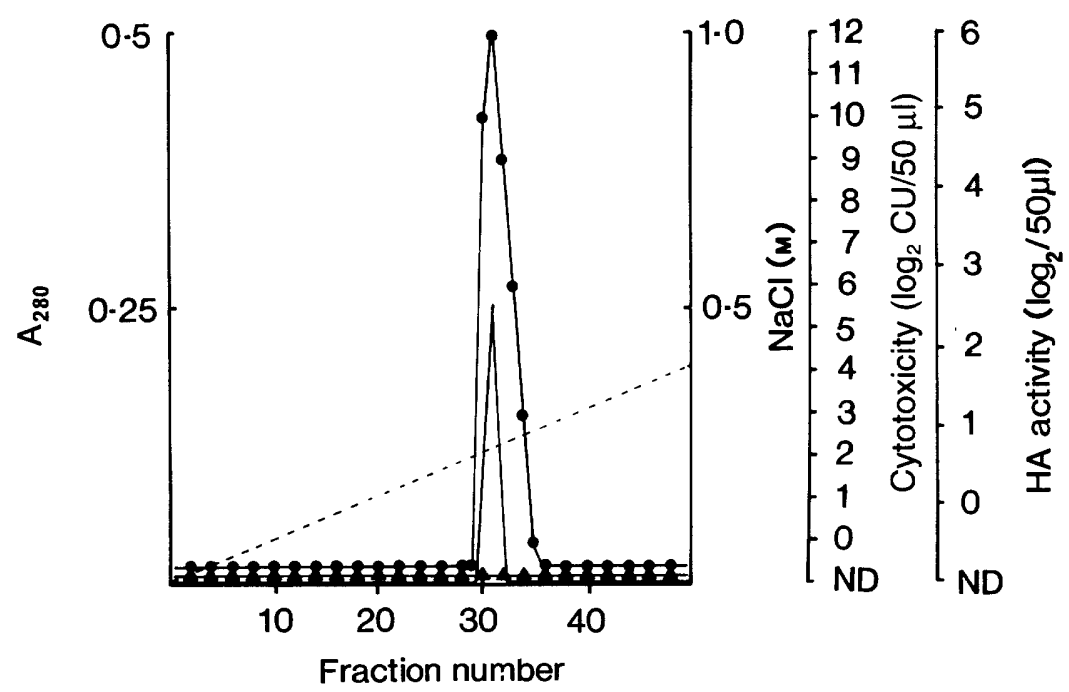

Fig. 3. Mono Q anion-exchange chromatography profile of the intracellular toxin A preparation obtained by the first Mono Q-FPLC. Cytotoxic fractions (fr 30-32) without HA activity in the first Mono Q-FPLC were applied again to a Mono Q column after dialysis. Symbols are the same as in fig. 2. 
Table I. Purification yield of intracellular toxin A of $C$. difficile

\begin{tabular}{|c|c|c|c|c|c|c|c|c|}
\hline Step & $\begin{array}{l}\text { Volume } \\
\qquad(\mathrm{ml})\end{array}$ & $\begin{array}{c}\text { Protein } \\
\text { content } \\
(\mathrm{mg} / \mathrm{ml})\end{array}$ & $\begin{array}{l}\text { Total } \\
\text { protein } \\
(\mathrm{mg})\end{array}$ & $\begin{array}{l}\text { Cytotoxicity } \\
(\mathrm{CU} / \mu \mathrm{l})\end{array}$ & $\begin{array}{c}\text { Total } \\
\text { cytotoxicity } \\
\text { (CU) }\end{array}$ & $\begin{array}{l}\text { Specific } \\
\text { activity } \\
(\mathrm{CU} / \mathrm{mg})\end{array}$ & $\begin{array}{c}\text { Fold } \\
\text { purification }\end{array}$ & $\begin{array}{l}\text { Percentage } \\
\text { yield }\end{array}$ \\
\hline Sonication & 60 & $3 \cdot 6$ & 216 & $1 \cdot 16 \times 10^{5}$ & $1.39 \times 10^{8}$ & $6.44 \times 10^{5}$ & - & - \\
\hline TGAC & 21 & 0.020 & 0.420 & $4.50 \times 10^{2}$ & $1.89 \times 10^{5}$ & $4.50 \times 10^{5}$ & 1.00 & 100 \\
\hline $\begin{array}{l}\text { First } \\
\text { Mono Q }\end{array}$ & 3 & 0.042 & $0 \cdot 126$ & $1.81 \times 10^{3}$ & $1.09 \times 10^{5}$ & $8.65 \times 10^{5}$ & 1.92 & $57 \cdot 7$ \\
\hline $\begin{array}{l}\text { Second } \\
\text { Mono Q }\end{array}$ & 1.5 & 0.030 & 0.045 & $1.81 \times 10^{3}$ & $5.43 \times 10^{4}$ & $1.21 \times 10^{6}$ & $2 \cdot 69$ & $28 \cdot 7$ \\
\hline
\end{tabular}

Cytotoxicity to BHK-21/WI-2 cells.

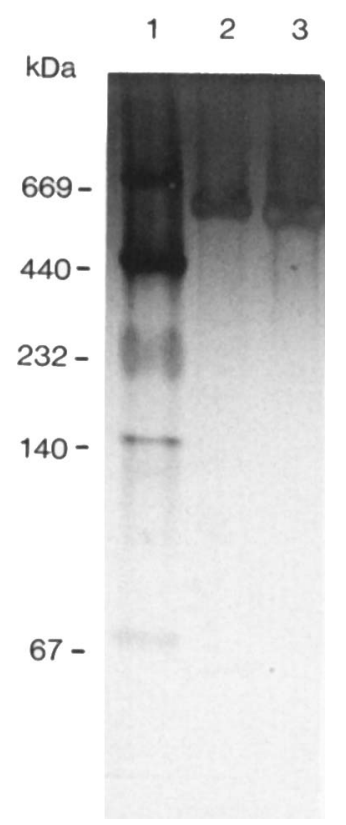

Fig. 4. Analysis of intracellular and extracellular toxin $\mathrm{A}$ by native PAGE (4-15\%) developed by silver stain. Lane 1, mol. wt markers: thyroglobulin $(669 \mathrm{kDa})$, ferritin $(440 \mathrm{kDa})$, catalase $(232 \mathrm{kDa})$. lactate dehydrogenase (140 $\mathrm{kDa})$. bovine serum albumin $(67 \mathrm{kDa})$; 2, purified intracellular toxin $\mathrm{A}(2.5 \mu \mathrm{g}): 3$, extracellular toxin $\mathrm{A}$ $(2.5 \mu \mathrm{g})$ purified by the methods of Kamiya et al. ${ }^{10}$

recovered and 2.69-fold purification was achieved in the final preparation.

\section{$P A G E$}

The final preparation of intracellular toxin A was analysed by native PAGE to check the purity and $\mathbf{M}_{r}$ in non-denaturing conditions (fig. 4). The intracellular toxin A preparation exhibited one band $(580 \mathrm{kDa})$ developed by silver stain, indicating that the toxin was highly purified. The $\mathrm{M}_{\mathrm{r}}$ of extracellular toxin A was $40 \mathrm{kDa}$ lower than that of the intracellular form.

\section{Biological actirity of purified intracellular toxin $A$}

The biological activity of purified intracellular toxin A was examined. $\mathrm{CU}_{50}$ cytotoxicity assays and $\mathrm{LD}_{50}$ in mouse lethality assays were $0.83 \mathrm{ng}$ and $8.7 \mathrm{ng}$, respectively; $5 \mu \mathrm{g}$ of the toxin induced fluid accumulation with haemorrhage in the ligated ileal loop but $1 \mu \mathrm{g}$ had no effect.

The purified toxin A had no HA activity even at a concentration of $15 \mu \mathrm{g} / \mathrm{ml}$. Expression of HA activity of the toxin in vitro with ileal loop contents was attempted. A 50-cm long ileal loop was washed thoroughly with $10 \mathrm{ml}$ of sterile saline. The toxin $(50 \mu \mathrm{g} / \mathrm{ml})$ was mixed with the same volume of the washed contents, incubated at $37^{\circ} \mathrm{C}$ for $0 \cdot 5,1,2,4$ and $8 \mathrm{~h}$, and then subjected to HA assay. Cytotoxicity remained but $\mathrm{HA}$ activity was not detected in any of the mixtures.

\section{Discussion}

On the basis of the presence of the trisaccharide receptor (Gal $\alpha 1-3 \mathrm{Gal} \beta 1-4 \mathrm{GlcNAc})$ for toxin $A$ on bovine thyroglobulin, ${ }^{12}$ TGAC was developed for the purification of toxin $A$ released into the culture medium (extracellular toxin A). ${ }^{9,10}$ This is an excellent single step method which can be further improved if followed by anion-exchange chromatography. ${ }^{10}$ In this study, toxin A in the sonic extract of cells (intracellular toxin A) was purified by TGAC followed by successive anion-exchange chromatography.

The TGAC profile of the cell extract was different from that of extracellular toxin A reported before $;^{10}$ in cell extracts, toxin A with poor HA activity was eluted at $37^{\circ} \mathrm{C}$ and $\mathrm{HA}$ activity was present in TGACunbound fractions eluted at $4^{\circ} \mathrm{C}$. In considering that toxin $\mathrm{A}$ binds through binding sites in the HA-activity component to the trisaccharide receptor in TGAC, it would be expected, theoretically, that the minimum numbers of binding sites needed for binding to thyroglobulin and for causing HA would be one and two, respectively. Therefore, we considered that the toxin A with poor $\mathrm{HA}$ activity in thermal eluates would express binding sites sufficient to bind to thyroglobulin but not to cause $\mathrm{HA}$ by its configuration, and that HA activity in TGAC-unbound fractions may have no relationship to toxin $\mathrm{A}$. When the TGAC-unbound fractions were analysed by Mono Q column chromatography, HA activity without cytotoxicity was eluted faster than toxin $\mathrm{A}$, with high cytotoxicity shown by fractions at the position of toxin $\mathrm{B}$, supporting the postulate outlined above. We are now attempting to purify the HA-positive substance. Recently, Kamiya and Borriello ${ }^{15}$ obtained a highly cytotoxic but weakly haemagglutinating variant 
of toxin $\mathrm{A}$, which they designated toxin $\mathrm{A}^{\prime}$, from TGAC-unbound fractions of culture filtrate. In culture filtrates, due to the presence of larger amounts of haemagglutinating form of toxin $\mathrm{A}$, poor or nonhaemagglutinating forms would pass more readily through TGAC.

The increase in HA activity of the thermal eluates after dialysis against $0.02 \mathrm{M}$ Tris- $\mathrm{HCl}(\mathrm{pH} \mathrm{7.5)}$ was demonstrated. It is possible that small molecules inhibiting $\mathrm{HA}$ activity might be removed by dialysis. It is also possible that a significant decrease of $\mathrm{NaCl}$ concentration might induce configurational change of the intracellular toxin $\mathrm{A}$, resulting in the increase of HA titre.

On Mono Q-FPLC, the toxin was eluted with $0-1.0 \mathrm{M} \mathrm{NaCl}$ gradient at a flow rate of $1 \mathrm{ml} / \mathrm{min}$ (each fraction, $1.0 \mathrm{ml}$ ). Under these conditions, the peaks of HA and cytotoxic activities were different, indicating that there might exist conditions whereby these two peaks can be separated more distinctively. Therefore, we examined several chromatographic conditions on Mono Q-FPLC, and, as shown in this study, could clearly separate two peaks, when the toxin was eluted with $0-0.4 \mathrm{M} \mathrm{NaCl}$ gradient at a flow rate of $0.5 \mathrm{ml} / \mathrm{min}$ (each fraction, $0.5 \mathrm{ml}$ ). On the second Mono Q-FPLC under these conditions, the highly purified intracellular toxin A which had no detectable HA activity but was highly cytotoxic $\left(2^{12} \mathrm{CU} / 50 \mu \mathrm{l}\right)$ was obtained. However, it should be noted that there were fractions with cytotoxicity and HA activity and in these fractions cytotoxicity and HA activity decreased concomitantly on the first Mono Q-FPLC. These findings seem to indicate that, although a non-haemagglutinating form represents most of the intracellular toxin, a haemagglutinating form might also be present. As toxin A with poor or no HA activity and the toxin with high

\section{References}

1. Sullivan NM, Pellett S, Wilkins TD. Purification and characterization of toxins A and B of Clostridium difficile. Infect Immun 1982; 35: 1032-1040.

2. Banno $\mathrm{Y}$, Kobayashi $\mathrm{T}$, Kono $\mathrm{H}$, Watanabe $\mathrm{K}$, Ueno $\mathrm{K}$, Nozawa Y. Biochemical characterization and biologic actions of two toxins (D-1 and D-2) from Clostridium difficile. Rev Infect Dis 1984; 6 Suppl 1: S11-S20.

3. Lyerly DM, Roberts MD, Phelps CJ, Wilkins TD. Purification and properties of toxins $\mathrm{A}$ and $\mathrm{B}$ of Clostridium difficile. FEMS Microbiol Lett 1986; 33: 31-35.

4. Lyerly DM, Krivan HC, Wilkins TD. Clostridium difficile: its disease and toxins. Clin Microbiol Rev 1988; 1: 1-18.

5. Borriello SP, Welch AR, Barclay FE, Davies HA. Mucosal association by Clostridium difficile in the hamster gastrointestinal tract. J Med Microbiol 1988; 25: 191196.

6. Seddon SV, Hemmingway I, Borriello SP. Hydrolytic enzyme production by Clostridium difficile and its relationship to toxin production and virulence in the hamster model. $J$ Med Microbiol 1990; 31 : 169-174.

7. Borriello SP, Davies HA, Barclay FE. Detection of fimbriae amongst strains of Clostridium difficile. FEMS Microbiol Lett 1988; 49: 65-67.

8. Davies HA, Borriello SP. Detection of capsule in strains of Clostridium difficile of varying virulence and toxigenicity. Microbial Pathogen 1990; 9: 141-146.

9. Krivan HC, Wilkins TD. Purification of Clostridium difficile
HA activity are present in culture filtrate,,$^{15}$ and this study has shown that toxin A without HA activity is present in relatively large amounts in cell extracts, it might be speculated that toxin $A$ is synthesised in cells as the non-haemagglutinating form and then processed to express HA activity.

The $\mathbf{M}_{r}$ of the intracellular toxin A with nondetectable HA activity in non-denaturing conditions was estimated to be $580 \mathrm{kDa}$ which is slightly larger than that of extracellular toxin $\mathrm{A}$; both toxin $\mathrm{A}$ with potent HA activity and toxin A with poor or nondetectable $\mathrm{HA}$ activity have a $\mathrm{M}_{\mathrm{r}}$ of $540 \mathrm{kDa} \cdot{ }^{10,15}$ The difference was ascertained when intracellular toxin A and extracellular toxin A with potent $\mathrm{HA}$ activity were analysed simultaneously by native PAGE. This finding suggests that a small molecule ( $40 \mathrm{kDa})$ may act as an HA inhibitor and be cleaved during release of toxin A from the cells into the culture medium.

The minimum dose $\left(\mathrm{CU}_{50}, 0.83 \mathrm{ng}\right)$ of intracellular toxin A causing cytotoxicity was within the range of previous reports. ${ }^{1,3,16}$ The minimum dose $\left(\mathrm{LD}_{50}\right.$, $8.7 \mathrm{ng}$ ) causing mouse lethality was less than that reported for extracellular toxin A. ${ }^{1-3}$ This may be due partly to a difference in the unit between $\mathrm{LD}_{50}$ and minimum lethal dose (MLD). The intracellular toxin A $(5 \mu \mathrm{g})$ without HA activity induced fluid accumulation with haemorrhage in the ileal loop test. We could not activate the toxin to show HA activity by contact with ileal loop contents in vitro. However, these findings do not mean that enterotoxicity and HA are unrelated. It seems that toxin A without HA activity possesses sufficient binding sites to bind to intestinal epithelial cells but not to cause HA.

This work was supported in part by a Grant-in-Aid for Scientific Research (No. 03670208) from the Ministry of Education, Science and Culture of Japan.

toxin A by affinity chromatography on immobilized thyroglobulin. Infect Immun 1987; 55: 1873-1877.

10. Kamiya S, Reed PJ, Borriello SP. Purification and characterization of Clostridium difficile toxin A by bovine thyroglobulin affinity chromatography and dissociation in denaturing conditions with or without reduction. $J \mathrm{Med}$ Microbiol 1989; 30: 69-77.

11. Nakamura S, Mikawa $\mathrm{M}$, Nakashio $\mathrm{S}$ et al. Isolation of Clostridium difficile from the feces and the antibody in sera of young and elderly adults. Microbiol Immunol $1981 ; 25$ : 345-351.

12. Krivan HC, Clark GF, Smith DF, Wilkins TD. Cell surface binding site for Clostridium difficile enterotoxin: evidence for a glycoconjugate containing the sequence Gal $\alpha 1$ 3Gal $\beta 1-4 G l c N A c$. Infect Immun 1986; 53: 573-581.

13. De SN, Chatterje DN. An experimental study of the mechanism of action of Vibrio cholerae on the intestinal mucous membrane. J Pathol Bacteriol 1953; 66: 559-562.

14. Bradford MM. A rapid and sensitive method for the quantitation of microgram quantities of protein utilizing the principle of protein-dye binding. Anal Biochem 1976; 72: $248-254$

15. Kamiya S, Borriello SP. A non-haemagglutinating form of Clostridium difficile toxin A. J Med Microbiol 1992; 36: 190-197.

16. Aronsson B, Grauström M, Möllby R, Nord CE. Enzyme immunoassay for detection of Clostridium difficile toxins A and $B$ in patients with antibiotic-associated diarrhoea and colitis. Eur J Clin Microbiol 1985; 4: 102-107. 